\title{
"Effectiveness of planned teaching programme on knowledge regarding ill effects of alcohol consumption."
}

\author{
Vaibhav jani ${ }^{1}$, Swamy $\mathrm{PGN}^{2}$, Ravindra H.N ${ }^{3}$, Ruhi varghese ${ }^{4}$ \\ ${ }^{1}$ Student, Sumandeep Nursing College, Sumandeep Vidyapeeth, Piparia, Vadodara-391760, Gujarat, India, \\ ${ }^{2}$ Associate Professor, Department Of Community Health Nursing, Sumandeep Nursing College, Sumandeep \\ Vidyapeeth, Piparia, Vadodara-391760, Gujarat, India. \\ ${ }^{3}$ Principal, Sumandeep Nursing College, Sumandeep Vidyapeeth, Piparia, Vadodara-391760, Gujarat, India, \\ ${ }^{4}$ Lecturere, Department Of Community Health Nursing, Sumandeep Nursing College, Sumandeep Vidyapeeth, \\ Piparia, Vadodara-391760, Gujarat, India.
}

\begin{abstract}
In this study an evaluative research approach with pre-experimental design was used. The sampling technique used was non - probability convenient sampling. Data was collected from 60 adolescents from selected higher secondary school Vadodara district. Data was analyzed using descriptive and inferential statistics Descriptive statistics used were frequency, mean, range and standard deviation. The results of the study is in pre test adolescents were having on average $43.43 \%$ knowledge regarding ill effects of alcohol consumption and mean score was $12.43 \pm 2.645$ and in post test, average $65.33 \%$ knowledge regarding ill effect of alcohol consumption and mean score was 19.60 2.599.T calculated value of -20.948 which is less than the tabulated value of 2.00 at 0.05 level of significance. So we accept H1 and conclude that there is significant difference between pre-test and posttest knowledge score of adolescents. It is found that from the entire variable only one variable that is domicile significantly associated with pre test knowledge score hence the hypothesis (H2) was partially accepted for these variables.
\end{abstract}

\section{Introduction}

"Drink has drained more blood, hung more crepe, sold more house, plunged more people bankruptcy, armed more villains, slain more children, snapped more wedding rings, defiled more innocence, blind more eyes, twisted more limbs, dethroned more reason, wrecked more manhood, dishonored more womanhood, broken more hearts, blasted more lives driven more to suicide, and dug more graves than only other poisoned scourge that ever swept its death dealing waves across the world".

Alcohol abuse is a major health problem in the country and at large in the world. For the past thirty to forty years, alcohol consumption has increased tremendously. The problem of alcoholism, until a few decades was considered a moral problem and a sign of social irresponsibility. Recently scholars consider it as a more complicated chronic and immensely costly disease than type of a deviant behavior.Alcohol dependence is pervasive and destructive yet highly treatable disease. The age at which people start drinking has declined. Taking alcohol even once in a leaves the possibility of a habit forming phenomenon open and the drinker may start drinking frequently and large quantity, which could have drastic effects on this health. ${ }^{2}$

Alcoholism is defined as chronic dependence characterized by compulsive drinking of alcohol to such a degree that produces mental disturbances and interferes with social and economic functioning. ${ }^{3}$

According to Johnson (1973) alcoholism is a condition in which an individual loses control over his alcohol intake. He is constantly unable to refrain from drinking once he begins. According to Keller and Efron (1955) alcoholism is characterized by the repeated drinking of alcoholic beverages to an extent that exceeds customary se of compliance with the social customs of the commonly and that adversely effects the drinkers health or interfere with this social or economic functioning. ${ }^{4}$

\section{Statement Of The Problem}

“A STUDY TO EVALUATE THE EFFECTIVENESS OF PLANNED TEACHING PROGRAMME ON KNOWLEDGE REGARDING ILL EFFECTS OF ALCOHOL CONSUMPTION AMONG ADOLESCENTS OF SELECTED HIGHER SECONDARY SCHOOL OF VADODARA DISTRICT".

\section{Objective Of The Study}

1. To assess the pre test level of knowledge regarding ill effect of alcohol consumption among adolescents of selected higher secondary school of Vadodara district.

2. To evaluate the effectiveness of planned teaching programme regarding ill effects of alcohol consumption among the adolescent of selected higher secondary school of Vadodara district. 
3. To find out the association between pre test knowledge scores regarding ill effects of alcohol consumption with selected socio demographic variables.

\section{Hypothesis}

H1- There will be significant difference between pre test and post test knowledge score of adolescents regarding ill effect of alcohol consumption.

H2- There is a significant association between pre test knowledge scores of adolescents regarding ill effect of alcohol consumption of selected with their selected demographic variables.

\section{Materials And Methods}

Research Approach: evaluative approach was used.

Research Design: Pre- experimental one group pre-test and post-test design was adopted.

Setting of the Study: The setting of the present study was Heaven higher secondary school and Astha vidhyalay varasada in Vadodara district.

Target Population: The population of this study comprising adolescents of Heaven higher secondary school and Astha vidhyalay varasada in Vadodara district.

Sample: The sample of the study comprised of 60 adolescents school students studying in Heaven higher secondary school and Astha vidhyalay varasada in Vadodara district.

Sampling technique: In this study non probability convenience sampling technique use. Who were easily accessible to the researcher and who needs the criteria of the study..

\section{Development of tool for data collection:}

After an experience review of literature and discussion with the experts, a structured knowledge questionnaire was prepared to assess the knowledge on ill effect of alcohol consumption among adolescents. The final tool comprised of two parts.

- Part I - Demographic forms, It consist age, gender, religion, type of family, educational status of parents, occupational status of parents, family income, family history of alcoholism.

- Part II - Structured knowledge questionnaire. It consist 30 questions. All items are given score of one for each correct answer and zero for wrong answer.

Validity of instrument: Content validity was established by 07 experts comprising of 06 nursing experts from community health nursing department and mental health nursing department, 01 biostatistician. $100 \%$ agreement on all items of the tool except the correction made in the tool and content. The final content was prepared as per the suggestions and advice given by the experts.

Reliability: The tool after validation was subjected to test for its reliability. The questionnaire was administered to six students. The reliability was established by using split half technique and spearman's brown prophecy formula. So tool was found to be highly reliable for data collection.

Data collection procedure: The research investigator obtained the ethical clearance and formal permission fromthe selected higher secondary school Vadodara district and approval was obtained to conduct the study. The data collection procedure was carried out from 20-11-2013 to $27-11-2013$ for the period of one weeks. The investigator himself collected both pre test and post test data and also implemented planned teaching programme. Pretest was conducted on the first day for 60 11th-12th standard students. Structured knowledge questionnaire was administered. They were instructed to go through the instruction before proceeding to answer the questionnaire.A planned teaching programme administered with the help of PPT Flash card, hand out black board for easy understanding to the 11th-12th standard students. It was conducted for one hour.The posttest that is the same knowledge questionnaire was administration on the seventh day of teaching programme for the students to assess effectiveness of plan teaching programme.

Analysis of data: For the present study, the data obtained were analyzed in respect to the objectives of the study by using descriptive and inferential statistics. The plan of data analysis was worked out with the experts in the field of statistics and nursing.

The plan of data analysis is as follows: 
- Organize data in master sheet / computer.

- Frequency and percentage for the analysis of demographic data.

- Mean, median, mode, standard deviation of pretest and posttest scores.

- Paired ' $t$ ' test for testing effectiveness of planned teaching programme and research

hypothesis.

- ANOVA TEST would be applied to determine association between pre test score and demographic variable.

\section{Results}

The data is analyzed and presented under the following sections:

SECTION I: Description of Sample Characteristics.

Baseline data containing sample characteristics would be analyzed using frequency and percentage

SECTION II: Determine pre test knowledge score of adolescents regarding ill effects of alcohol consumption.

SECTION III: Analysis of effectiveness of plan teaching program regarding ill effect of alcohol consumption.

- Comparison of pre-test and post-test knowledge scores of adolescents

regarding ill effect of alcohol consumption.

SECTION IV: Association of demographic variable with pre test knowledge score.

\section{SECTION I: - Description of Sample Characteristics.}

- Age wise distribution of sample reveals that 98.3 percents respondents belong to the age group of 1618 years and also $1.7 \%$ respondents belong to age group $14-16$ years.

- Gender wise distribution of sample reveals majority (63.3) percentage of the respondents were males and (36.7) percentage of the respondents were female.

- Religious wise distribution of sample reveals that $93.3 \%$ respondents were Hindu and $3.3 \%$ were Christian and remaining 3.3\% were Muslims.

- Family type wise distribution of sample reveals that $38.3 \%$ respondents belong to nuclear family and $51.7 \%$ were belongs to joint family and remaining $10 \%$ were extended family.

- domicile wise distribution of sample reveals that $33.3 \%$ respondents were belonging to rural area and $66.7 \%$ were belonging to urban area .

- father education wise distribution of sample reveals that 43.3 respondent's father were study up to Studied up to middle school,38.3 percent respondent's father were study up to Studied up to higher secondary school and 18.3 percent respondent's father were study up to Graduate and above.

- Mother education wise distribution of sample reveals that 53.3 respondent's mother were study up to Studied up to Studied up to middle school, 45.0 percent respondent's mother were study up to Studied up to higher secondary school and 1.7 percent respondent's mother were study up to Graduate and above.

- Father occupation wise distribution of sample reveals 3.3 percent respondent's father is teacher , 8.3 percent respondent's father are agriculture,1.7 percent respondent's father is factory worker and 86.7 percent respondent's are have any specify worker.

- Mother occupation wise distribution of sample reveals .91 .7 percent respondent's mother are house wife, 8.3 percent respondent's mother is any specific worker.

- Family income wise distribution of sample reveals that 3.3 percent respondent's family income is below 5000 Rs , 11.7 percent respondent's family income is between 5000 - 10,000 Rs,48.3 percent respondent's family income between 10,000-15,000 Rs and 36.7 percent respondent's family income above 15,000 Rs.

- Family history wise distribution of sample reveals that 100 percent repondent'shave nofamily history

SECTION II: - Determine pre test knowledge score of adolescents regarding ill effects of alcohol consumption.

\begin{tabular}{|c|c|c|c|c|c|}
\hline \multicolumn{6}{|c|}{ TABLE.1 MEAN SCORE OF PRE TEST } \\
\hline & $\mathrm{N}$ & MINIMUM & MAXIMUM & MEAN & $\begin{array}{c}\text { STD. } \\
\text { DEVIATION }\end{array}$ \\
\hline TOTAL & 60 & 5 & 17 & 12.43 & 2.645 \\
\hline
\end{tabular}

Overall pre test mean knowledge score was found to be (12.43) and standard deviation (2.645) among the respondents.

SECTION III: Analysis of effectiveness of plan teaching program regarding ill effect of alcohol consumption. 
"Effectiveness of planned teaching programme on knowledge regarding ill effects of alcohol

\begin{tabular}{|c|c|c|c|c|c|c|c|c|}
\hline $\begin{array}{l}\text { Total no } \\
\text { of } \\
\text { questions }\end{array}$ & Observation & percentage & Mean & S.D & $\begin{array}{l}\text { Mean } \\
\text { difference }\end{array}$ & $\begin{array}{l}\mathrm{T} \\
\text { calculated } \\
\text { value }\end{array}$ & $\begin{array}{l}\mathrm{T} \\
\text { tabulated } \\
\text { value }\end{array}$ & significance \\
\hline \multirow[t]{2}{*}{30} & PRE-TEST & $43.43 \%$ & 12.43 & 2.645 & \multirow[t]{2}{*}{7.167} & \multirow[t]{2}{*}{-20.948 } & \multirow[t]{2}{*}{2.00} & \multirow[t]{2}{*}{.000} \\
\hline & $\begin{array}{l}\text { POST TEST } \\
\end{array}$ & $65.33 \%$ & 19.60 & 2.599 & & & & \\
\hline
\end{tabular}

The data from the above table shows that in pre test, adolescents were having on average $43.43 \%$ knowledge regarding ill effect of alcohol consumption and mean score was $12.43 \pm 2.645$ and in post test, average $65.33 \%$ knowledge regarding ill effect of alcohol consumption and mean score was $19.60 \pm 2.599$. T calculated value of -20.948 which is less than the tabulated value of 2.00 at 0.05 level of significance. So we accept $\mathrm{H} 1$ and conclude that there is significant difference between pre-test and post- test knowledge score of adolescents. It shows the very highly significant and association between pre-test and post-test knowledge score of ill effect of alcohol consumption. Hence research hypothesis H1 is accepted.

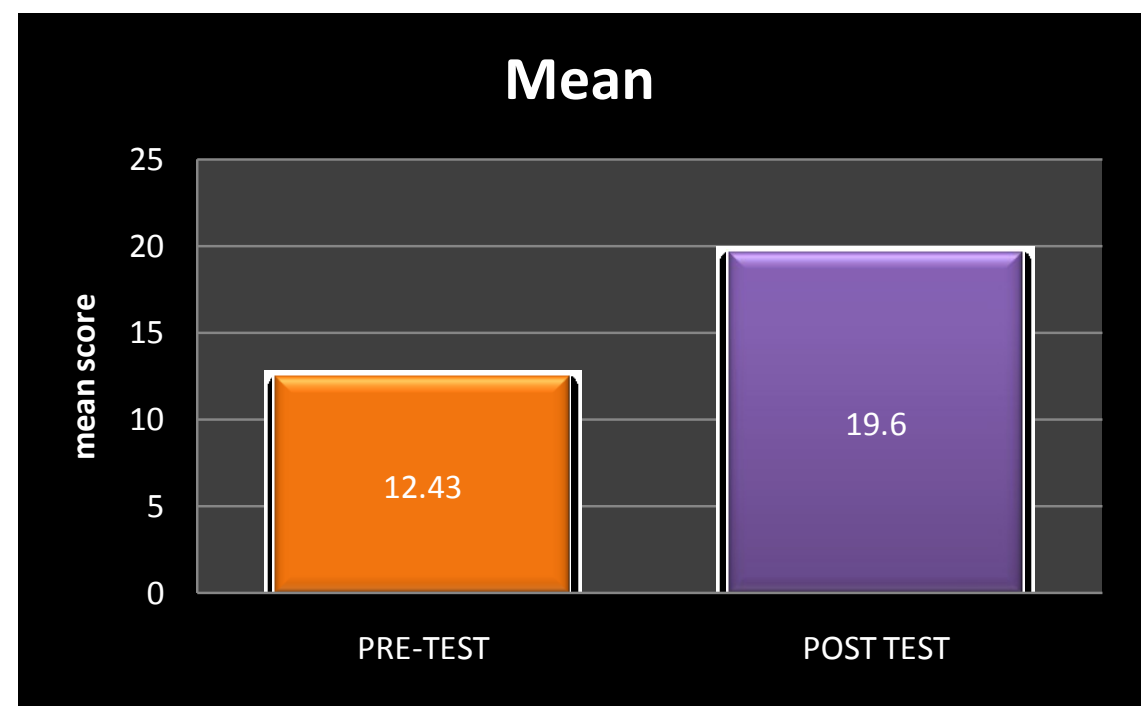

FIG NO:1 Classification of mean score of pre test and post test

SECTION IV: Association of demographic variable with pre test knowledge score.

Analysis of variance (ANOVA) was used instead of chi-square to determine the association between the pre test knowledge score and selected demographic variables.

\begin{tabular}{|c|c|c|c|c|c|c|c|}
\hline \multicolumn{8}{|c|}{ Table no. 3 association between pre test and demographic variable } \\
\hline \multicolumn{2}{|c|}{ Demographic Variables } & Mean & $\mathrm{N}$ & S.D. & $\mathrm{F}$ & P Value & Significance \\
\hline \multirow{2}{*}{ 1.Age in years } & $14-16$ & 16.00 & 1 & 0.02 & \multirow{2}{*}{1.877} & \multirow{2}{*}{.176} & \multirow{2}{*}{ NS } \\
\hline & $16-18$ & 12.37 & 59 & 2.625 & & & \\
\hline \multirow{2}{*}{ 2.Gender } & Male & 12.43 & 38 & 1.571 & \multirow{2}{*}{.023} & \multirow{2}{*}{.977} & \multirow{2}{*}{ NS } \\
\hline & Female & 1241 & 22 & 1.781 & & & \\
\hline \multirow{3}{*}{ 3.Religion } & Hindu & 12.48 & 56 & 2.601 & \multirow{3}{*}{.581} & \multirow{3}{*}{.562} & \multirow{3}{*}{ NS } \\
\hline & Christians & 10.50 & 2 & 4.950 & & & \\
\hline & Muslim & 13.00 & 2 & 2.828 & & & \\
\hline \multirow{3}{*}{ 4.type of family } & Nuclear & 12.70 & 23 & 2.098 & \multirow{3}{*}{.956} & \multirow{3}{*}{.390} & \multirow{3}{*}{ NS } \\
\hline & Joint family & 12.03 & 31 & 2.881 & & & \\
\hline & Extended & 13.50 & 6 & 3.271 & & & \\
\hline \multirow{2}{*}{ 5.domicile } & Rural area & 11.15 & 20 & 3.265 & \multirow{2}{*}{7.887} & \multirow{2}{*}{.007} & \multirow{2}{*}{$\mathrm{S}$} \\
\hline & Urban area & 13.08 & 40 & 2.030 & & & \\
\hline \multirow{3}{*}{$\begin{array}{l}\text { 6.educational } \\
\text { status of father }\end{array}$} & $\begin{array}{l}\text { Studied up middle } \\
\text { school }\end{array}$ & 13.04 & 26 & 2.537 & \multirow{3}{*}{1.498} & \multirow{3}{*}{.232} & \multirow{3}{*}{ NS } \\
\hline & $\begin{array}{l}\text { Studied up to higher } \\
\text { secondary school }\end{array}$ & 11.74 & 23 & 2.973 & & & \\
\hline & Graduate and above & 12.45 & 11 & 1.916 & & & \\
\hline \multirow{3}{*}{$\begin{array}{l}\text { 7.educational } \\
\text { status of mother }\end{array}$} & $\begin{array}{l}\text { Studied up middle } \\
\text { school }\end{array}$ & 12.69 & 32 & 2.583 & \multirow{3}{*}{919} & \multirow{3}{*}{.405} & \multirow{3}{*}{ NS } \\
\hline & $\begin{array}{l}\text { Studied up to higher } \\
\text { secondary school }\end{array}$ & 12.04 & 27 & 2.724 & & & \\
\hline & Graduate and above & 15.00 & 1 & . & & & \\
\hline
\end{tabular}


"Effectiveness of planned teaching programme on knowledge regarding ill effects of alcohol

\begin{tabular}{|c|c|c|c|c|c|c|c|}
\hline \multirow{4}{*}{$\begin{array}{l}\text { 8.Occupation of } \\
\text { father }\end{array}$} & Teacher & 14.00 & 2 & 1.414 & \multirow{4}{*}{.876} & \multirow{4}{*}{.459} & \multirow{4}{*}{ NS } \\
\hline & Agriculture & 12.20 & 5 & 1.789 & & & \\
\hline & Factory worker & 16.00 & 1 & . & & & \\
\hline & Any other & 12.33 & 52 & 2.728 & & & \\
\hline \multirow{2}{*}{$\begin{array}{l}\text { 9. Occupation of } \\
\text { mother }\end{array}$} & House wife & 12.35 & 55 & 2.689 & \multirow{2}{*}{.725} & \multirow{2}{*}{.398} & \multirow{2}{*}{ NS } \\
\hline & Any other & 13.40 & 5 & 2.074 & & & \\
\hline \multirow{4}{*}{$\begin{array}{l}10 . \\
\text { income }\end{array}$} & Below 5000 & 12.50 & 2 & .707 & \multirow{4}{*}{.485} & \multirow{4}{*}{.694} & \multirow{4}{*}{ NS } \\
\hline & $5000-10,000$ & 13.57 & 7 & 2.936 & & & \\
\hline & $10000-15000$ & 12.31 & 29 & 3.048 & & & \\
\hline & Above 15,000 & 12.23 & 22 & 2.069 & & & \\
\hline $\begin{array}{ll}11 . & \text { Family } \\
\text { history } & \end{array}$ & No & 12.43 & 60 & 2.645 & & & \\
\hline
\end{tabular}

Table no. 3 depicts that only one domicile demographic variable is significantly associated with pre test knowledge score regarding ill effects of alcohol consumption among adolescents and other demographic variable is not significantly associated with pre test knowledge score.

\section{Conclusion}

The research approach adopted in the present study is an evaluative research approach with a view to measure the knowledge on ill effects of the alcohol consumption. Effectiveness was assessed by analysis of pre test and post test knowledge score to know the effectiveness of plan teaching programme. The data was interpreted by suitable and appropriate statistical method.

\section{Acknowledgement}

I express my gratitude and thanks towards all who have directly or indirectly helped me to complete this study and their support in each major step of the study.

\section{Limitations Of The Study}

Health is every one's right and primary prevention is an important aspect in promoting health. In this study adolescents from selected higher secondary school who can read and write English and gujrati only were involve. Generalization would have been if adolescent boys from all the higher secondary school of Vadodara were included in the study. An increased sample size and duration of the study would allow an evaluation of the effects and duration of the intervention.

\section{Recommendations}

On the basis of the finding of the present study the following recommendation are made.

1) An experimental study could be conducted to find out an effective way of imparting education regarding ill effects of alcohol among adolescents of higher secondary school.

2) An experimental study could be carried out using peer education method to educate adolescents of higher secondary school.

3) A comparative study may be carried out in knowledge related to ill effects of alcohol consumption between literate and ill literate youth.

4) Conducting similar studies the tool used in the study can be standardized.

5) An exploratory study can be conducted to assess the knowledge of nurses and health professional in the community regarding ill effects of alcohol consumption.

\section{Ethical Standards}

This study was conducted after getting approval from the Institutional Ethics Committee and after obtaining written consents from all subjects.

Source of funding: The authors did not receive any financial support from any third party related to the submitted work.

Conflict of interest: The authors had no relationship/condition/circumstances that present a potential conflict of interest. 


\section{References}

[1]. Vasumathi. An exploratory study to determine the relationship betweenknowledge and attitude towards alcoholism among Pre University student inMangalore [Master degree in Nursing]; Rajiv Gandhi University of health science 2001.

[2]. Sreevani R. A guide to mental health and psychiatric nursing: Substance abuse. 2nd ed. New Delhi: Jaypee publication; 2004. p. 8690.

[3]. Alcoholism. [Online]. 2008 Aug 16 [cited 2004 Aug 16]; Available from:URL:http://www.WHO.com/htm/org

[4]. Gincy. A study to assess knowledge and attitude of adolescent towards alcoholism in a selected community in Udupi District [Master degree in Nursing]; University of Manipal; 1999. 